The Ultimate Enemy 
A volume in the series

Cornell Studies in Security Affairs

edited by

Robert J. Art

Robert Jervis

Stephen M. Walt

A list of titles in the series is available at www.cornellpress.cornell.edu. 


\title{
The Ultimate Enemy
} BRITISH INTELLIGENCE AND

NAZI GERMANY, 1933-1939

\author{
WESLEY K. WARK
}


Copyright (C) 1985 by Cornell University

All rights reserved. Except for brief quotations in a review, this book, or parts thereof, must not be reproduced in any form without permission in writing from the publisher. For information, address Cornell University Press, Sage House, 512 East State Street, Ithaca, New York 14850.

First published 1985 by Cornell University Press

First printing, Cornell Paperbacks, 2010

Printed in the United States of America

A CIP catalog record for this book is available from the Library of Congress. 
For " $\mathrm{C}$ " 
This page intentionally left blank 